Volume 23, number / numéro 1 Spring / printemps 2011

\title{
HISTORICAL STUDIES IN EDUCATION
}

\section{REVUE D'HISTOIRE DE L'ÉDUCATION}





\title{
Historical Studies in Education Revue d'histoire de l'éducation
}

\author{
Co-editors / Paul Axelrod \\ Corédacteurs Faculty of Education, York University, Canada \\ Rosa Bruno-Jofré \\ Faculty of Education, Queen's University, Canada \\ Jocelyne Murray \\ (French Language Editor/Rédactrice francophone) \\ Québec, Canada \\ Elizabeth Smyth \\ OISE, University of Toronto, Canada
}

Book Review Editor (French) / Rédactrice des comptes rendus ouvrages en français

Book Review Editor (English) / Rédactrice des comptes rendus ouvrages en anglais

Advisory Board / Comité consultatif Canada
Jocelyne Murray

Québec, Canada

Catherine Gidney

St. Thomas University

Paul Aubin

Université Laval, Université du Québec à Trois-Rivières, Canada

Sara Burke

Laurentian University, Canada

Louise Bienvenue

Université de Sherbrooke, Canada

Craig Campbell

University of Sydney, Australia

Bruce Curtis

Carleton University, Canada

Gonzalo Jover

Catedràtico de Teoria de la Educatiòn, Spain

Kay Morris Matthews

Victoria University of Wellington, New Zealand

Lisa Panayotidis

University of Calgary, Canada

Rebecca Rogers

Université René-Descartes Paris 5, France

Philippe Savoie

Service d'histoire de l'éducation INRP/ENS, France

Daniel Tröhler

Research Insititute for the History of Education, Switzerland

Wayne Urban

University of Alabama, United States

Co-managing editors / secrétaires à la rédaction
Angela Romano and Daniel Ross

York University, Canada 
La Revue d'histoire de l'éducation est publiée deux fois l'an, au printemps et à l'automne, par L'Association canadienne d'histoire de l'éducation.

Toute correspondance concernant la publicité doit être adressée au Secrétariat à la rédaction, Revue d'histoire de l'éducation/Historical Studies in Education, York University, 4700 Keele St., Toronto, Ontario, M3J 1P3 (paxelrod@edu.yorku.ca); toute correspondance concernant les comptes rendus (anglais) doit être adressée à Prof. Catherine Gidney, Department of History, St. Thomas University, Fredericton, New Brunswick, Canada E3B 5G3 (cgidney@stu.ca); et toute correspondance concernant les comptes rendus (français) doit être adressée à Jocelyne Murray, 2290, avenue Rodrigue-Masson, Québec, QC, G1T1M8 (jocelynemurray@videotron.ca).

Les << Lignes directrices pour les auteur-es >> paraissent à la page 116.

Site internet : http://library.queensu.ca/ojs/index.php/edu_hse-rhe/index

Historical Studies in Education is published twice annually, in Spring and Fall, by the Canadian History of Education Association.

Address all correspondence concerning advertising to the Managing Editor, Historical Studies in Education, Faculty of Education, York University, 4700 Keele St., Toronto, Ontario, M3J 1P3 (paxelrod@edu.yorku.ca); all correspondence concerning book reviews (English) to Prof. Catherine Gidney, Department of History, St. Thomas University, Fredericton, New Brunswick, Canada E3B 5G3 (cgidney@stu.ca); and all correspondence concerning book reviews (French) to Jocelyne Murray, 2290, avenue Rodrigue-Masson, Québec, QC, G1T1M8 (jocelynemurray@videotron.ca).

"Guidelines for Authors" appear on page 114.

Website: http://library.queensu.ca/ojs/index.php/edu_hse-rhe/index

Historical Studies in Education/Revue d'histoire de l'éducation is indexed in/est indexée dans CBCA Education; Historical Abstracts; America: History \& Life; Sociology of Education Abstracts; Contents Pages in Education; Educational Research Abstracts (ERA) online.

ISSN 0843-5057 (Print)

ISSN 1911-9674 (Online)

Historical Studies in Education/Revue d'histoire de l'éducation

Volume 23, number / numéro 1

Spring / printemps 2011

Print version produced by the York University Bookstore, York University, 4700 Keele St. Toronto, Ontario, Canada, M3J 1P3 


\section{Note from the Editors}

At its biennial conference, held in Toronto, October 21-24, 2010, the Canadian History of Education Association took a bold step with respect to the future of this journal. It resolved to make HSE/RHÉ "a fully on-line, open access, peer-reviewed journal beginning with the [current] Spring 2011 issue. Printed versions of the journal would continue to be available to interested readers." In light of continuing change in the world of academic journal publishing, the journal is taking this action for a number of reasons. HSE/RHE will be accessible immediately to all readers, thus ensuring a far broader circulation of new research in the history of education. The costs of online distribution will be minimal since the journal already uses the Open Journal Systems (OJS) online management system. The task of administering journal subscriptions will end because there will no longer be official subscribers. Nor will there be subscription fees. Printing and mailing costs will be radically reduced, though printed journals will still be available at a modest cost to those wishing to purchase them. The journal will continue to qualify for funding support from the Social Sciences and Humanities Research Council of Canada, which, if renewed, will cover the journal's editorial costs. Thus, readers and libraries around the world are now able to access HSE/RHE online at no cost. We are enthusiastic about this exciting initiative and welcome our current readers' and contributors' continuing association with the journal as it enters a new phase.

\section{Message de la rédaction}

Lors de son congrès biennal tenu à Toronto du 21 au 24 octobre 2010, l'Association canadienne d'histoire de l'éducation a effectué un virage important pour l'avenir de la Revue. L'Association a résolu de faire de la HSE/RHÉ une revue « entièrement en ligne, libre d'accès, avec comité de lecture, commençant avec le numéro du printemps 2011 [le present numéro]. Une version papier de la Revue demeurerait disponible pour les lecteurs intéressés ". Étant donné les changements actuels dans le monde des publications scientifiques, la Revue effectue cette démarche pour plusieurs raisons. La HSE/ RHÉ sera disponible immédiatement à tous les lecteurs, assurant ainsi une plus grande diffusion des nouvelles recherches dans le domaine de l'histoire de l'éducation. Les frais d'une distribution en ligne seront négligeables puisque la Revue utilise déjà le progiciel Open Journal Systems (OJS) pour son contenu en ligne. La tâche de gestion des abonnements sera éliminée du fait qu'il n'y aura plus d'abonnés officiels. S'ensuit la fin des frais d'abonnement. Les coûts associés à l'impression et à l'envoi des exemplaires de la Revue seront drastiquement réduits, bien qu'une version papier restera disponible à un prix raisonnable. La Revue restera admissible aux subventions du Conseil de recherches en sciences humaines du Canada, un soutien qui, si renouvelé, suffirait à couvrir les coûts de rédaction de la Revue. Donc, les lecteurs et les bibliothèques du monde entier ont désormais accès au contenu de la HSE/RHÉ sans frais. C'est avec enthousiasme que nous vous présentons cette nouvelle orientation de la Revue et que encourageons nos lecteurs et nos collaborateurs à participer avec nous à ce nouveau défi. 


\section{Thanks / Remerciements}

French translation and copy editing / Traduction et édition française :

Jocelyne Murray

English and French translation / Traduction anglaise et française

Daniel G. Ross

English copy editing / Édition anglaise :

Angela Romano

Desktop publishing and layout / Édition et mise en page :

Steve Knowles, The Right Type

Print copies / Version papier

Steve Glassman, York University Bookstore

Cover photo / Photo de couverture

(c) Can Stock Photo, Inc.: ronfromYork 


\section{Table of Contents / Table des matières}

\section{Articles/Articles}

Up Against 'Edutopia': Dr. James Daly's Crusade against the Spectre of Progressive Education, 1968-1983

Paul W. Bennett

The French Third Republic: Popular Education, Conceptions of Citizenship and the Flemish Immigrants

Marc Depaepe and Walter Kusters

"I Thought the People Wanted to Get Rid of the Teacher":

Educational Authority in Late-Nineteenth Century Ontario Jennifer Anne Goldberg

"Children Who Drill, Seldom Are Ill." Drill, Movement and Sport: The Rise and Fall of a Female Tradition in Ontario Elementary Physical Education (1850s to 2000)

Nancy R. Francis and Anna H. Lathrop

\section{Book Reviews/Comptes rendus}

Review Essay. Equal Citizenship of the Mind: Recent Studies in the History of Women's Education.

Rita Hofsetter. Genève : creuset des sciences de l'éducation.

Normand Baillargeon

Olga Hazan. La culture artistique au Québec au seuil de la modernité.

Susan K Freeman. Sex Goes to School: Girls and Sex Education before the 1960s.

Karen L. Graves. And They Were Wonderful Teachers: Florida's Purge of Gay and Lesbian Teachers. 
John F. Lyons. Teachers and Reform:Chicago Public Education, 1929-1970.

$$
\text { Harry Smaller }
$$

Léo-Paul Hébert. Les clercs de Saint-Viateur au Canada, 1947-1997.

$$
\text { Dominique Laperle }
$$

Sharon Wall. The Nurture of Nature: Childhood, Antimodernism, and Ontario Summer Camps, 1920-55.

Anna H. Lathrop

Larry Prochner. A History of Early Childhood Education in Canada, Australia, and New Zealand.

Nicholas L. Syrett. The Company He Keeps: A History of White College Fraternities.

$$
\text { Jeffery Vacante }
$$

Contributors / Collaborateurs 